\title{
Give Me More Body: Pushing the Boundaries of Body and Soul
}

\author{
Alford A. Young, Jr.
}

In Body and Soul: Notebooks of an Apprentice Boxer, Loïc Wacquant offers a lively and insightful commentary not so much about the sport of boxing, but about the functioning of men's bodies in boxing. Indeed, a significant part of this work elucidates the functioning of the black male body. Wacquant conducted his study in a boxing gymnasium on Chicago south's side, an area that has long stood as one of the most renowned African American residential sectors in urban America. The gymnasium is located in the Woodlawn section of that city, which is an impoverished, overwhelmingly African American neighborhood that sits at the southern edge of the considerably more affluent Hyde Park community area. It is in Hyde Park white collar professionals and the faculty, administrators, at students at the University of Chicago often reinforce their anxiety and insecurity about the neighboring communities (Woodlawn being just one of them) by often trying to preserve as much distance as possible between themselves and the residents of these bordering spaces. Wacquant also draws from his own experiences in training in this gym and in competing in a boxing match in order to centrally position his own (Caucasian) body in this book. In fact, one chapter of this work centers on Wacquant's experiences, even though much of the point of this part of the material is to express some understanding of the more general social, emotional, and psychological dynamics at work in the enterprise.

All together, Wacquant covers broad terrain in a book that appears at first glance to be about the sweet science of boxing. His analysis moves beyond the ring, and beyond the gymnasium as well, in that he gives analytical attention to the neighborhood as a pervasive social factor affecting what goes on in the gym. In focusing on boxers' bodies Wacquant consistently informs his readers of the pain, discipline, energy, and commitment that constitutes the practice of pugilism.

Correspondence should be directed to Alford Young, Jr., Department of Sociology, University of Michigan, 1225, S. University, Ann Arbor, MI 48104; e-mail: ayoun@umich.edu. 
He demonstrates how this holds for all serious practitioners, and not solely for those who rise to championship caliber or even second-tier contender status in the profession. When placing the craft of boxing and the Woodlawn gymnasium within the broader context of the community Wacquant expounds upon the role that the sport serves for men who otherwise must manage the tribulations of living in low-income Chicago. For instance, he elucidates how the gym operates as a safe haven for men who encounter unpredictability and inconsistency in the social milieu that remains beyond the gym's doors. While in the gym, then, the boxers find at least one dimension of their lives that provides them with the capacity to represent themselves as disciplined, dedicated and honorable individuals in pursuit of life goals that others would take as at least legitimate, and possibly even praiseworthy. This is in contrast to their lives beyond the gym, where they have to contend with a turbulent and threatening social world that consistently delivers public denigration to those that inhabit it.

In looking at the relationship of the gym to the social world immediately outside of it Wacquant also explains how social arrangements in low-income urban life affect the kinds of men who invest their lives into the sport. Here he offers a sociologically-informed commentary about how boxers do not often emerge from the lowest strata in low-income communities because men from such arenas can rarely develop the degree of commitment and focus necessary to advance in the profession. However, Wacquant does not fall back upon a trite cultural logic that forwards that such men simply lack the values associated discipline, patience, and maturity. Instead, he responsibly and effectively argues that the delayed gratification inherent in the world of boxing (represented by both the money that boxers may acquire after years of cumulative success in the sport, and the enhanced skill and efficacy that results from long-term, intensive training) is not tenable for men who must dedicate significant time and energy to making ends meet on a day-to-day basis or who are preoccupied with personal or familial crises that interfere with their capacity to commit appropriately to the demands of a career in boxing. Moreover, as Wacquant points out, some of the men from the lowest tier of the urban socio-economic hierarchy do not develop the "soft" skills required for success in boxing. He makes this point by drawing from the remarks of DeeDee, the manager of the gym, who at one point speaks about the lack of talent form some of the "heathens" from the "projects." ${ }^{1}$ Such skills are constituted by possession of the technical ability to box rather than the physical capacity to brawl, and the faculty to know how to outscore an opponent rather than how beat him as severely as possible.

\footnotetext{
${ }^{1}$ It should be made clear, in order to be fair to DeeDee's argument, that he does not denigrate all products of public housing. In fact, in the course of making his remarks he heaps praise upon Riddick Bowe, a former New York City public housing resident who, at the time of the fieldwork, was a rising star among heavyweight fighters and eventually spent a brief period in his career as a world champion.
} 
Finally, Wacquant tells an explicit story about himself in Body and Soul. This story is not the commonplace tale built out of articulations about how a researcher immersed him or herself into a field site, but rather one that can only be produced out of Wacquant's effort to fully engage the very activity that is the centerpiece of his study. In other words, Wacquant took not only a tape recorder and notebook to the gym, but placed his own body in the training regiment there, and eventually in the ring, itself. He became a participant who observes, thus sedimenting him further into the sphere of his study than is often the case for most ethnographer. ${ }^{2}$ As Body and Soul is a commentary about black bodies and Wacquant's own body, the challenges and triumphs that are parts of a boxer's experience become a part of Wacquant's as well. The move that Wacquant makes in putting his body into the analysis is both critical and effective in that he does not aspire to be exactly like the men that he studies-indeed he makes explicit throughout his book how much he could not be. Wacquant recognizes that the men in the gym have more at stake than he does in the game of boxing. They have been at it for a significantly longer period of time, and they have life experiences that situate them with respect to the sport in ways that differ from those in his life history and his purposes for being in the gym. Perhaps the best portrayal of the ultimate distance between him and the men that he studied is delivered in the final paragraph of the book, where, after his chapter-long description in rich detail of his experience in his first and only boxing match, he states:

I feel like a soldier going back to base camp after having been at the front lines, I'm so bombarded with high-fives, smiles, winks, pats on the shoulder, compliments, and commentary on the refereeing. "You done got robbed, Louie!" I surprised everyone at the gym - starting with myself. From now on, I am fully one of them; "Yep, Louie's a soul brother." Ashante is eagerly inquiring about my next fight when DeeDee shuts the party down. "There ain't gonna be no next time. You had yo' fight. You got enough to write your damn book now. You don't need to get into d'ring (p. 255)."

In closing his book in this way Wacquant delivers a very clear depiction of how he believed himself to have been situated in this study. Discussions of situatedness are often trivialized in many ethnographies. That is, the discussion is reduced to commentary about how rapport or insider status was achieved as a precursor to moving more fully into the findings generated by the fieldwork. However, in Wacquant's case, this paragraph demonstrates the extent to which he is in, but not all the way in, as a participant in the community of boxers at the Woodlawn gym. It is not a problem-neither for Wacquant's ability to deliver on his project nor for the reader to benefit from it - that he can train in the gym, participate in a boxing match, but not be in as much as most of the other fighters

${ }^{2}$ A similar effort at sedimentation of this sort is found in the work of Carol Rambo Ronai who studied the work experiences of erotic dancers, in part by evaluating her own experiences as one $(1989,1992)$. Hence, like Wacquant, she places her body within her analyses. However, she does not explore with equivalent analytical depth the internalization of bodily experience, largely because her analytical point of focus is on the clients' gaze at, and interaction with, her body. Consequently, a very different form of carnal disposition takes center stage in her work. 
are. After all, Wacquant's aim for entering into this world is to conduct a study, not become a contender. His key informants and associates knew this, and thus interacted with him (as far as we can tell given that we only have his own reporting on the matter) with this understanding in mind. Consequently, in making explicit that he was in, but not all they way in, Wacquant allows us complete outsiders (re: readers of his book) to acquire a sensitive and deep appreciation for the body work that goes on in the gym (and in boxing more generally) because we can assess what is going on for these boxers by attending to Wacquant's account of what is going on with his own body. In this way, the subtitle, "Notebooks of an Apprentice Boxer" becomes no minor statement in capturing the flavor of this work. Wacquant is an apprentice to the physical experience that stands at the center of his study. Consequently, he literally and deeply feels, rather than simply reflects upon, that which he aims to interpret.

With so much attention to bodies-the boxers in the gym as well as Wacquant's - it may seem puzzling for a reviewer to, as the title of my essay asserts, desire even more body. Yet it is Wacquant's skillful positioning of himself in this analysis that inspires me issue such a request. By this I mean that we acquire a clear sense of the (literal) pain that Wacquant encounters as he begins training in the gym, and we acquire a sense of the rhythm and mood of the craft of boxing as Wacquant talks about his and the other boxers' experiences. We do not get a sense of the rhythms and moods of the full range of boxers, however, that stand between men like Wacquant and the more dedicated of the gym's brood. In between these ends are men who remain consistently out of shape, lack the requisite type of commitment, or for some other reason enter fight only to make a quick payday in the course of building up some other, more talented, fighters' record. We also do not get a more thorough sense of the trials and tribulations of the rough-necks who never develop the fine-tuned skills of good boxers, but who manage to carve out some kind of meager career in the sport. Most importantly, we never get a more thorough sense of how Wacquant's Caucasian body is read by the members of the gym from the moment when he enters their world to begin training up until his fight (where he clearly has garnered the respect of his associates by doing what few commentators on the sport-ethnographers or not-have ever done). Much more about what is going on for black bodies in boxing would be revealed by more explicit reference to what these men did and how they responded to Wacquant's non-black body in that space.

To be clear, I do not mean that Wacquant needs to offer up some hackneyed account of how he garnered intimate connection to the members of the boxing club such that he could conduct his study. ${ }^{3}$ Instead, I point to the value of extrapolating

\footnotetext{
${ }^{3}$ I explore what I believe to be some shortcomings of this narrowed framing of the relationship of researchers to the people that they study - too simplistically construed as the insider versus outsider positioning of the researcher - in "Experiences in Ethnographic Interviewing about Race: The Inside and Outside of It" (Young 2004).
} 
more fully on the often subtle - and inherently more revealing and provocativesocial interactions and publicly expressed revelations concerning someone so unlike the usual members of this gym coming into their midst. Loic Wacquant's entering into the Woodlawn boxing gymnasium clearly amounts to something more meaningful than a story of an outsider's effort to gain entry into such a seemingly unusual site for someone like him. Hence, my interest in whatever might have been moments of curiosity, concern, confusion, intrigue, or conflict associated with his presence in the way that it came to be in this gym have little to do with a desire to understand more about Wacquant's immersion into the scene. Instead, precisely because Wacquant puts his body both on the line and in the text in the ways that he does creates a hunger for exploration of the more analytically insightful point of how the men in the gym make sense of themselves as boxers and as disadvantaged black men by their exchanges and interactions with someone like him (and how this holds for men in each of the various classifications of fighters that I mentioned earlier). Essentially, a more thorough investigation of how these men reacted to Wacquant's body in that space (including his being a researcher on the site, a trainee in gym, a boxer in the ring, and a friend in social interaction outside of the gym) would provide the reader with a more complete and furtherreaching insight into these men's sensibilities about their bodies, and how they articulate that bodily sensibility as athletes, as men, and as highly marginalized citizens of the United States. ${ }^{4}$ Many of these issues are acknowledged and implied throughout the book, but each could be more fully illustrated and made more applicable to different kinds of black men/boxers if carried out under a rubric that emphasizes more broadly Wacquant's body. That Loic Wacquant has written a book that calls attention to these issues is remarkable in and of itself. Accordingly, if the measure of good scholarship is the extent to which it stimulates critical questions for further inquiry, then Body and Soul will deservedly occupy a place among the important books of our time on the relationship of sport, race, and masculinity.

\section{REFERENCES}

Ronai, C. R., \& Ellis, C. (1989). Turn-ons for money: Interactional strategies of the table dancer. Journal of Contemporary Ethnography, 19, 271-298.

Ronai, C. R. (1992). The reflexive self through narrative: A night in the life of an exotic dancer/researcher. In C. Ellis \& M. G. Flagherty (Eds.), Investigating subjectivity: Research on lived experience. London: Sage Publications.

\footnotetext{
${ }^{4} \mathrm{~A}$ provocative commentary on the process of such meaning making and articulation is provided by Sudhir Venkatesh (2002) in his account of how low-income, African American residents of the Robert Taylor Homes, a Chicago-based public housing development, tried to make sense of his ethnicity and his interests in exchanging with them. Venkatesh argues that periodic moments of questioning and discussion on these topics between him and the residents of the Homes served as analytical terrain for him to extrapolate the residents' sense of their own social citizenship and social standing in American society.
} 
Venkatesh, S. (2002). Doing the Hustle: Constructing the Ethnographer in the American Ghetto. Ethnography, 3, 91-111.

Young, A. A., Jr. (2004). Experiences in ethnographic interviewing about race: The inside and outside of it?" In J. Solomos \& M. Bulmer (Eds.), Researching Race and Racism (pp. 187-202). New York: Routledge Press. 